\title{
INFLUENCE OF AIR, OXYGEN, NITROGEN AND ARGON ON 400 nm LUMINESCENCE IN HEXAGONAL BORON NITRIDE
}

\author{
V. Korsaks, B. Berzina, L. Trinklere \\ Institute of Solid State Physics, University of Latvia, \\ 8 Kengaraga Str., LV-1063, Riga, LATVIA \\ e-mail: valdis.korsaks@gmail.com
}

\begin{abstract}
The investigation is devoted to the influence of different surrounding gases on the defect-related luminescence in hexagonal boron nitride (hBN). The photoluminescence spectra of $\mathrm{hBN}$ powder were measured for an hBN sample placed in different surroundings formed by ambient air, vacuum, as well as oxygen, nitrogen and argon gases. It was found that the $400 \mathrm{~nm}$ luminescence caused by native defects in $\mathrm{hBN}$ is sensitive to the oxygen gas and ambient air. Presence of oxygen gas around $\mathrm{hBN}$ considerably reduces the intensity of this luminescence. The results evidence that hBN powder can successfully be applied as the material for oxygen sensors.
\end{abstract}

Key words: photoluminescence, hexagonal boron nitride, oxygen sensor.

\section{INTRODUCTION}

Hexagonal boron nitride (hBN) is a promising wide-band gap material for possible application as the light emitter within a far ultraviolet (FUV) spectral region [1]. This application is based on excitonic processes, therefore exciton luminescence is well studied in hBN materials with different modifications - such as single crystals, macrosize polycrystalline powders and nanotubes ([2] and Refs. therein).

The defect-related luminescence in $\mathrm{hBN}$ has not been so thoroughly examined. Wu et al. [3] report the luminescence of native defects in $\mathrm{hBN}$ to be within the wavelength region above $250 \mathrm{~nm}$. One intensive band with a fine structure was observed at $320 \mathrm{~nm}$ and some others - in the $380-400 \mathrm{~nm}$ range. The $320 \mathrm{~nm}$ luminescence is sufficiently well investigated [4-6]. Recently, we studied luminescence of native defects in macrosize polycrystalline $\mathrm{hBN}$ powder and multiwall nanotubes (BNNTs) [7-9]. The native defects can be formed from impurities such as $\mathrm{O}$ and $\mathrm{C}$ atoms (which are characteristic for the boron nitride), and from various imperfections of the crystalline host lattice such as boron and nitrogen vacancies $\left(\mathrm{v}_{\mathrm{B}}, \mathrm{v}_{\mathrm{N}}\right)$, as well as interstitials and Stone-Walls' defects where the number of atoms in the elemental hexagonal ring is changed. More intensive luminescence bands are observed at $320 \mathrm{~nm}$ and $400 \mathrm{~nm}$, and their properties have also been studied [4-6].

The aim of our investigation was to reveal the influence of different surrounding gases on the native defect luminescence in $\mathrm{hBN}$ when the samples are placed in the ambient air, vacuum as well as oxygen, nitrogen and argon gases. 


\section{EXPERIMENTAL}

We used hBN powder consisting of macrosize polycrystalline grains (Aldrich Corp.) The grain size of the material was estimated to be within $1 \mu \mathrm{m}-$ $10 \mu \mathrm{m}$ range, and the material purity was up to 99.5 atom\%.

The sample for investigation was prepared inserting $\mathrm{hBN}$ powder into a special holder using light pressing. Before the measurements the sample was heated up to $420{ }^{\circ} \mathrm{C}$ in air to remove humidity, then cooled down to the room temperature (RT) and put into a special camera (the element of a CCS-100/204 cryostat (Janis Research Co.)) allowing realization of various environmental conditions. The gases used for filling the camera were: oxygen, nitrogen and argon, with purity of $99.5 \%$ and humidity of $200 \mathrm{ppm}$.

The setup for luminescence measurements consists of a deuterium lamp (400W) for luminescence excitation and two monochromators. One of them is used for filtering the exciting light and the other one (Andor SR 303i) together with a CCD camera - for recording the luminescence spectra visualized on the screen of display.

All measurements were taken at RT and normal atmosphere pressure of gases filling the cryostat camera with the sample.

\section{RESULTS AND DISCUSSION}

The photoluminescence (PL) spectra of hBN measured at RT and $266 \mathrm{~nm}$ excitation corresponding to different gases are shown in Fig. 1. The spectra are complex, consisting of two main bands at $400 \mathrm{~nm}$ and $320 \mathrm{~nm}$ resulting from the native defects. The first PL spectrum after the heating process (with the lowest intensity) was measured when the sample was in ambient air. In the figure it is seen that the $320 \mathrm{~nm}$ luminescence is predominant, and its intensity exceeds that of $400 \mathrm{~nm}$. Afterwards, the air was pumped out from the camera and a vacuum level of $\mathrm{p}=3 \cdot 10^{-5}$ mbar was reached (solid curve with open circles). In Fig. 1 it is also seen that the intensity of $400 \mathrm{~nm}$ luminescence is growing for almost an order of magnitude, whereas that of $320 \mathrm{~nm}$ luminescence changes but slightly. The next step was filling the camera with oxygen gas, which resulted in a $38 \%$ reduced $400 \mathrm{~nm}$ luminescence, at the same time leaving the $320 \mathrm{~nm}$ luminescence unchanged. Then the oxygen gas was pumped out of the camera and the previous vacuum level was restored. The PL spectrum coincides with that measured previously under the same vacuum conditions. Filling the camera with nitrogen or argon gases does not affect the luminescence spectra, while in the case of its filling with ambient air $(\mathrm{O} \sim 21 \%$ and $\mathrm{N} \sim 79 \%)$ the $400 \mathrm{~nm}$ luminescence decreased by 17\% (a bold solid curve in Fig. 1); after the air was pumped out it did not reach the previous level in vacuum as it was in the case of pure oxygen. This could be explained with the dispersion of experimental measurement data.

The above results clearly testify the influence of oxygen gas on the luminescence of native defects in hBN. Presence of oxygen gas in hBN reduces the intensity of $400 \mathrm{~nm}$ luminescence, at the same time not affecting the $320 \mathrm{~nm}$ luminescence. This means that bleaching of the $400 \mathrm{~nm}$ luminescence could be related to oxygen, because in the presence of nitrogen and argon gases no changes in the $400 \mathrm{~nm}$ PL were observed. 


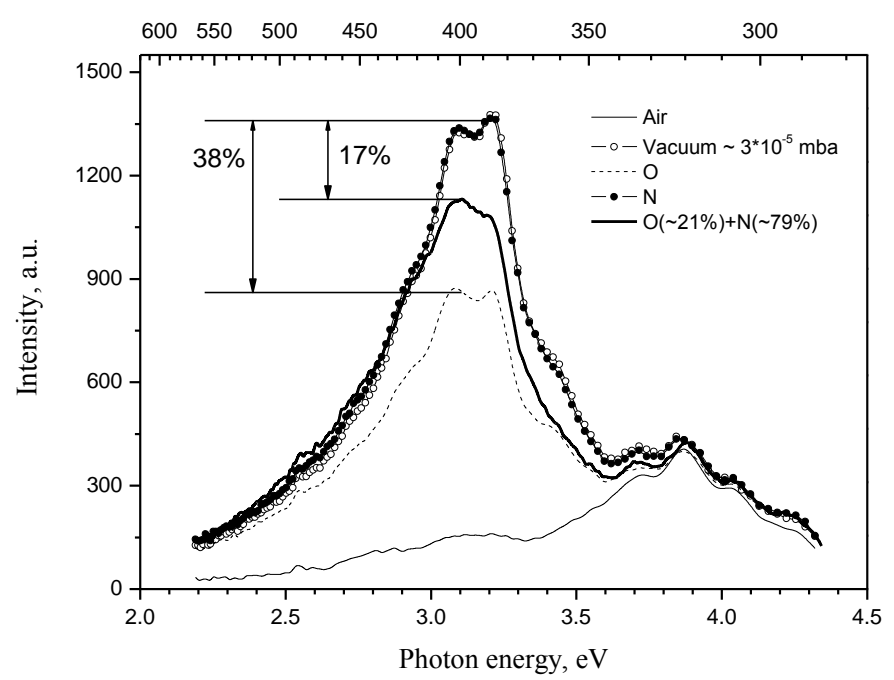

Fig. 1. Photoluminescence spectra of hBN powder (RT, $266 \mathrm{~nm}$ excitation) inserted in different environments: ambient air, vacuum, oxygen and nitrogen gases.

The spectral characteristics of $400 \mathrm{~nm}$ luminescence (see in our previous works $[8,9])$ throw light on its nature. The spectrum of this photoluminescence and its excitation spectrum for $\mathrm{hBN}$ at RT are shown in Fig. 2. This defect-related luminescence forms a wide band with a phonon-induced substructure, which is characterized with two excitation bands resulting from two absorption bands of defects. Nevertheless, the defects forming the luminescence center remain unknown $[10,11]$. The present investigation allows for the suggestion that these defects are situated either on the surface of the material or close to this surface being sensitive to oxygen from the gas surrounding the material. Regarding the $320 \mathrm{~nm}$ luminescence we can conclude that the corresponding luminescence centers are situated within the bulk of hBN and are not affected by environment conditions.

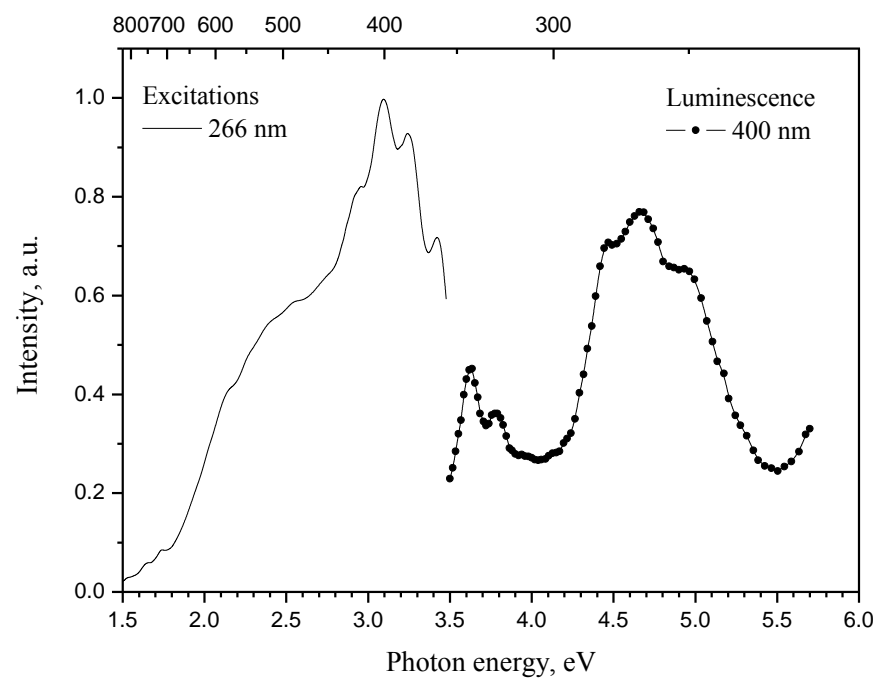

Fig. 2. Photoluminescence (solid curve) and its excitation spectrum (solid curve with black circles) of hBN at RT. The PL spectrum was measured at $266 \mathrm{~nm}$ excitation, and the luminescence excitation spectrum was obtained recoding $400 \mathrm{~nm}$ emission. 
The sensitivity of $400 \mathrm{~nm}$ luminescence in $\mathrm{hBN}$ to the presence of oxygen in ambient surrounding evidences that this material is potentially applicable as the oxygen sensor. The necessary investigations are going on.

\section{CONCLUSIONS}

From the results of measurements it follows that the $400 \mathrm{~nm}$ luminescence originates from the native defects located on the material surface in $\mathrm{hBN}$ powder and is sensitive to pure oxygen gas and ambient air. The presence of oxygen gas on the hBN material considerably reduces the intensity of $400 \mathrm{~nm}$ luminescence. The phenomena observed present evidence for potential hBN application as oxygen sensor material.

\section{ACKNOWLEDGMENTS}

The present research was supported from the National Research Program "IMIS", European Social Funds (ESF) and from the European project ERAF Nr 2010/0253/2DP/2.1.1.1.0/10/APIA/VIAA/079 to which we are deeply grateful.

\section{REFERENCES}

1. Watanabe, K., Taniguchi, T., Miya, K., Sato, Y., Nakamura K.,, Niiyama, T., \& Taniguchi, M. (2011). Hexagonal boron nitride as a new ultraviolet luminescent material and its application. Fluorescence properties of hBN single-crystal powder, Diamond and Related Materials, 20, 849-852. DOI: 10.1016/j.diamond.2011.04.002.

2. Watanabe, K., Taniguchi, T., \& Kanda, H. (2004). Ultraviolet luminescence spectra of boron nitride single crystals grown under high pressure and high temperature. Phys. Stat. Sol. (a), 201 (11), 2561-2565. DOI: 10.1002/pssa.200405188.

3. Wu, J., Han, W-Q., Walukiewicz, W., Ager, J.W., Shan, W., Haller, E.E., \& Zettl, A. (2004). Raman spectroscopy and time-resolved photoluminescence of $\mathrm{BN}$ and $\mathrm{BxCyNz}$ nanotubes. Nanoletters, 4 (4), 647-650. DOI: 10.1021/n1049862.

4. Taniguchi, T., \& Watanabe, K. (2007). Synthesis of high-purity boron nitride single crystals under high pressure by using Ba-BN solvent. J. Crystal Growth, 303, 525529. DOI: 10.1016/j.jcrysgro.2006.12.061.

5. Jaffrennou, P, Barjon, J., Lauret, J.-S., Attal-Trétout, B., Ducastelle, F., \& Loiseau, A. (2007). Origin of the excitonic recombinations in hexagonal boron nitride by spatially resolved cathodoluminescence spectroscopy, J. Appl. Phys., 102, 116102. DOI: http://dx.doi.org/10.1063/1.2821413.

6. J. Wu, Wei-Qiang Han, W. Walukiewicz, J. W. Ager, W. Shan, E. E. Haller, and A. Zettl. (2004). Raman Spectroscopy and Time-Resolved Photoluminescence of BN and BxCyNz Nanotubes, Nano Lett., (4), 647-650. DOI: 10.1021/n1049862e.

7. Berzina, B., Trinkler, L., \& Atobe, K. (2002). Spectral Characteristics of Native Defects in BN, Phys. Stat. Sol. (c), (1), 421-424. DOI: 10.1002/pssc.200390078.

8. Berzina, B., Trinkler, L., Korsaks, V., Krutohvostov, R., Carrol, D.L, Ucer, K.B., \& Williams, R.T. (2006). Exciton luminescence of boron nitride nanotubes and nanoarches. Phys. Stat. Sol. (b), 243 (14), 3840. DOI: 10.1002/pssb.200672108.

9. Williams, R.T., Ucer, K.B., Carroll, D.L., Berzina, B., Trinkler, L., Korsak, V., \& Krutohvostov, R. (2008). Photoluminescence of self-trapped excitons in boron nitride nanotubes. J. Nanosci. Nanotechnol., (8), 6504-6508. DOI: 10.1166/jnn.2008.005.

10. Grinyaev, S.N., Konusov, F.V., \& Lopatin, V.V. (2002). Deep levels of nitrogen vacancy complexes in graphite-like boron nitride. Phys. Solid State, 44, 286-293. DOI: $10.1134 / 1.1451015$. 
11. Tang, Yoshio Bando, Chunyi Zhi, \& Golberg, D. (2007). Boron-oxygen luminescence centres in boron-nitrogen systems. Chem. Commun., 4599-4601.

DOI: $10.1039 / \mathrm{b} 711807 \mathrm{~d}$.

\title{
HEKSAGONĀLĀ BORA NITRĪDA 400 nm LUMINISCENCES IZMAIN̦A GAISĀ, SKĀBEKLA, SLĀPEKL,A UN ARGONA GĀZĒES
}

\author{
V. Korsaks, B. Bērziņa, L. Trinklere
}

Kopsavilkums

Darbā pētīta dažādu gāzu ietekme uz hBN luminiscenci. Analizēti hBN fotoluminiscences spektri, paraugam atrodoties dažādās gāzēs: gaisā, skābeklī, slāpeklī, argonā, kā arī vakuumā. Ir atrasts, ka 400 nm luminescenci, kura ir saistīta ar dabīgiem defektiem hBN, ietekmē gāzveida skābekḷa sadarbība ar šo materiālu. Skābekḷa klātbūtne ap paraugu ievērojami samazina $400 \mathrm{~nm}$ luminiscences intensitāti. Novērotā parādība ļauj prognozēt hBN materiāla pielietojumu skābekḷa sensoru izveidei.

27.03.2012 